\title{
Evaluation of raw soapstone (steatite) as adsorbent of trace elements present in Brazilian spirits
}

\author{
Karine Aparecida Louvera Silva ${ }^{a}$, Isabela da Costa Fernandes ${ }^{a}$, Eduardo Bearzoti ${ }^{\mathrm{b}}$, \\ Raquel Fernanda Milani ${ }^{c}$, Marcelo Antonio Morgano ${ }^{c}$, Kesia Diego Quintaes ${ }^{\mathrm{a}, *}$ \\ a Ouro Preto Federal University (UFOP), Nutrition School (ENUT), Campus Morro do Cruzeiro, s/n, Ouro Preto, MG 35400-000, Brazil \\ b Ouro Preto Federal University (UFOP), Statistic Department (DEEST), Campus Morro do Cruzeiro, s/n, Ouro Preto, MG 35400-000, Brazil \\ ' Institute of Food Technology (ITAL), Av. Brasil, 2880, Campinas, SP 13070-178, Brazil
}

\section{A R T I C L E I N F O}

Article history:

Received 17 September 2015

Received in revised form 27 December 2015

Accepted 6 January 2016

Available online 7 January 2016

\section{Keywords:}

Inorganic contaminants

Alcoholic beverages

Lead

Nickel

Copper

Mineral migration

\begin{abstract}
A B S T R A C T
The impact of soapstone (steatite) upon inorganic element contaminant concentrations in alcoholic beverages was investigated. Concentrations of $\mathrm{As}, \mathrm{Cd}, \mathrm{Cu}, \mathrm{Ni}$ and $\mathrm{Pb}$ levels in 8 Brazilian spirits plus an alcoholic simulant were initially measured, and then measured following each $24 \mathrm{~h}$ cycle of exposure to raw soapstone cups, for a total of 4 cycles/sample. The results were compared to the levels established by Brazilian and German regulations. The contact between the spirits and the soapstone reduced the Cu content by up to $50.4 \%$ and increased the Ni content by up to $622.2 \%$, especially in the first contact cycle. The exposure of spirits to the soapstone exhibits a linear reduction in the Pb content (18.3-54.5\%) while As and $\mathrm{Cd}$ levels remained unaltered throughout the experiments. In conclusion, crude soapstone in contact with alcoholic solutions acts as an adsorbent of trace elements $(\mathrm{Cu}$ and $\mathrm{Pb}$ ) while releasing $\mathrm{Ni}$.
\end{abstract}

(C) 2016 Elsevier Ltd. All rights reserved.

\section{Introduction}

Spirits are one of the most widely produced alcoholic beverages worldwide. In 2009 the global revenue of spirits was 94.31 billion U.S. dollars, and in 2015 the projected revenue of the global spirits industry is estimated to be about 113.78 billion U.S. dollars (Statista, 2015). Despite the fact that almost a quarter $(24.8 \%)$ of all alcohol consumed worldwide is in the form of unrecorded alcohol, of the recorded alcohol consumption, more than half is consumed in the form of spirits $(50.1 \%)$, followed by beer $(34.8 \%)$ and wine (8.0\%) (WHO, 2014).

In 2014 Brazil exported cane spirit to 66 countries, with a revenue of US\$18.33 million for the sale of 10.18 million liters. In terms of value, the main countries of destiny were: Germany, USA, France, Portugal, Paraguay and Italy, and in terms of volume the main countries of destiny were: Germany, Paraguay, Portugal, USA, France and Bolivia (IBRAC, 2014).

\footnotetext{
* Corresponding author at: Ouro Preto Federal University (UFOP), Nutrition School (DENCS-ENUT), Campus Morro do Cruzeiro, s/n, Ouro Preto, MG 35400-000, Brazil.

E-mail addresses: karinelouvera@gmail.com (K.A. Louvera Silva), isabela0107@ gmail.com (I. da Costa Fernandes), edbearzoti@yahoo.com.br (E. Bearzoti), raquel.milani@ital.sp.gov.br (R.F. Milani), morgano@ital.sp.gov.br (M.A. Morgano), kesiadq@gmail.com, kesia@gmail.com (K.D. Quintaes).
}

Cane spirit is obtained by distilling the fermented must of sugarcane juice and has some particular sensory characteristics, an alcohol degree of from $38 \%$ to $48 \%$ by volume at $20^{\circ} \mathrm{C}$, and can have added sugars of up to $6 \mathrm{~g} \mathrm{~L}^{-1}$ (Ministry of Agriculture, Livestock and Supply, 2005). It can be divided into its organic and inorganic fractions, the latter being constituted principally of metal and nonmetal ions such as aluminum (Al), arsenic (As), cadmium (Cd), calcium $(\mathrm{Ca})$, lead $(\mathrm{Pb})$, cobalt $(\mathrm{Co})$, copper $(\mathrm{Cu})$, chromium $(\mathrm{Cr})$, iron (Fe) and nickel (Ni), amongst others (Siebalde, Canuto, Lima, \& Silva, 2002).

$\mathrm{As}, \mathrm{Cu}$ and $\mathrm{Pb}$ contents above the levels permitted by Brazilian legislation were observed in cane spirits from the State of São Paulo, Brazil (Caldas, Raposo, Gomes Neto, \& Barbosa, 2009). In the State of Minas Gerais, Brazil, responsible for $44 \%$ of the Brazilian production (CEPA, 2008), it was found that $25 \%$ of the cane spirits produced in stills in the south of the state showed $\mathrm{Cu}$ contents above the level permitted by the legislation (Fernandes et al., 2007). Cane spirits coming from the Iron Quadrangle in Minas Gerais (QFMG), a region with many steatite deposits were also shown to contain $\mathrm{Cu}$ above the legal limits (Fernandes et al., 2013).

Evidence of the contamination of alcoholic beverages by metals has been found throughout the world. Researchers have reported that the quality control of the Greek beverage Mouro may be deficient as a function of variation in the $\mathrm{Pb}$ content (Soufleros, 
Mygdalia, \& Natskoulis, 2004), and wine commercialized in Hungary has shown elevated contents of $\mathrm{Cu}\left(20-640 \mu \mathrm{g} \mathrm{L}^{-1}\right), \mathrm{Pb}(6-$ $\left.90 \mu \mathrm{g} \mathrm{L}^{-1}\right)$ and $\mathrm{Cd}\left(0.05-16.5 \mu \mathrm{g} \mathrm{L}^{-1}\right)$, the amplitude of the values being explained by the diversity in origin of the beverage and also by the effect of additives and the equipment used in production (Ajtony et al., 2008). The raw materials, substances intentionally added, type of process and storage are also factors interfering in the metal contents of alcoholic beverages (Ibanez, CarreonAlvarez, Barcena-Soto, \& Casillas, 2008).

Despite the fact that alcoholic beverages have been classified as carcinogenic to humans, levels of inorganic elements such as lead or arsenic could further increase their carcinogenic potential (Lachenmeier, Przybylski, \& Rehm, 2012) Hence, the removal of inorganic contaminants from alcoholic beverages in order to conform to legal parameters, and reduce health risks to the consumer, is important.

A recent study provided evidence that the alcohol content of cane spirit and the time of exposure to steatite could influence the transference of inorganic contaminants (Fernandes et al., 2013). Nevertheless the interference of soapstone in the content of contaminants present in alcoholic beverages still needs to be better investigated. Thus the objective of this study was to evaluate the behavior of the inorganic contaminants ( $\mathrm{As}, \mathrm{Cd}, \mathrm{Cu}, \mathrm{Ni}$ and $\mathrm{Pb}$ ) present in commercial Brazilian cane spirits when submitted to contact in natura with soapstone cups, and evaluate if the amounts found before and after four 24-h cycles of exposure to steatite conformed with the maximum limits established by the Brazilian and German legislations (Ministry of Health, 1965, 2005; BGBl, 2002).

\section{Material and methods}

Eight distinct brands of cane spirit acquired on the market in Belo Horizonte and Ouro Preto (MG, Brazil) were studied. The selection criteria for the beverages integrating this study considered those produced in the QFMG region and registered in the Ministry of Agriculture (MAPA). In addition to the cane spirits, a simulated alcoholic beverage was also included in the experiment, produced using a $43 \%\left(\mathrm{v} \mathrm{v}^{-1}\right)$ ethyl alcohol solution (Merck, Darmstadt, Germany) diluted with deionized water (18.2 M $\Omega$ ). This additional treatment was carried out with the objective of evaluating the effect of the exposure of ethyl alcohol in natura to the steatite cups.

In parallel, twenty seven new soapstone cups, each with a volumetric capacity of approximately $20 \mathrm{~mL}$, derived from the district of Cachoeira do Brumado (Mariana, MG, Brazil), were evaluated. All the cups were washed with potable water using a soft new polymeric sponge and a dilute solution of a commercial detergent, followed by rinsing with potable water and distilled water. They were dried in an incubator at $150{ }^{\circ} \mathrm{C}$ for $10 \mathrm{~min}$. The cups were divided into groups of 3 units, giving a total of 9 groups.

The As, $\mathrm{Cd}, \mathrm{Cu}, \mathrm{Ni}$ and $\mathrm{Pb}$ contents were determined in the eight brands of cane spirit and in the ethyl alcohol solution before and after contact with the soapstone cups. A part of each of the cane spirits and the ethyl alcohol solution was poured into a group of three new, clean soapstone cups to $2 / 3$ of their capacity (approximately $14 \mathrm{~mL}$ ). They were then covered with a watch glass and maintained at a constant temperature and under artificial light, in order to prevent any external interference.

Aliquots of each cane spirit and of the ethyl alcohol were removed after $24 \mathrm{~h}$ of contact ( 1 cycle), and four sequential cycles ( $24 \mathrm{~h}$ each) were carried out. Between each cycle the cups were washed and dried as mentioned above. Samples were removed after each cycle for the chemical analyses using a sterile pipette, without any abrasion of the surface of the cup or loss of the contents. The homogenized samples were placed in previously decon- taminated glass beakers. The cycle times used were based on Fernandes et al. (2013) and also the fact that many soapstone containers are intended for long term exposure to alcoholic beverages (i.e. pots, barrels, flasks).

The concentrations of the elements $\mathrm{As}, \mathrm{Cd}, \mathrm{Cu}, \mathrm{Ni}$ and $\mathrm{Pb}$ were determined in each aliquot and also in duplicate blanks prepared in decontaminated glass beakers using the same volumes of liquid adopted for the sandstone cups. For each element the final concentrations were obtained by deducting the contents found in the blanks from the contents found in the aliquots.

\subsection{Determination of the inorganic contaminants}

For the determinations of $\mathrm{As}, \mathrm{Cd}, \mathrm{Cu}, \mathrm{Ni}$ and $\mathrm{Pb}, 5 \mathrm{~mL}$ aliquots of the cane spirit samples and of the simulant were transferred to sterile glass flasks and their volume reduced by half on a digestion block at $80^{\circ} \mathrm{C}$. A volume of $1.25 \mathrm{~mL}$ of $65 \%$ nitric acid was then added and heated at $95{ }^{\circ} \mathrm{C}$ for $2 \mathrm{~h}$. After cooling the solution was quantitatively transferred to a $25 \mathrm{~mL}$ volumetric flask and completed to volume with a $5 \%\left(\mathrm{v} \mathrm{v}^{-1}\right)$ nitric acid solution, prepared from concentrated 65\% nitric acid (Merck, Darmstadt, Germany) and diluted with deionized water (18.2 M $\Omega$ ) (Fernandes et al., 2013; López-Artíguez, Cameán, \& Repetto, 1996).

Analytical curves were constructed as from standard $1000 \mathrm{mg} \mathrm{L}^{-1}$ solutions of As, Cd, Cu, Ni and Pb (Merck, Darmstadt, Germany) in the interval from 0.005 to $1.0 \mathrm{mg} \mathrm{L}^{-1}$ for $\mathrm{As}, \mathrm{Cd}, \mathrm{Pb}$ and $\mathrm{Ni}$ and from 0.025 to $25 \mathrm{mg} \mathrm{L}^{-1}$ for $\mathrm{Cu}$.

\subsection{Equipment and operational conditions}

The contents of the elements under investigation were analyzed by means of emission spectrometry in duplicate, by direct aspiration from the cane spirit samples and simulant, mineralized with nitric acid. The equipment used was an emission spectrometer with a plasma source and inductive coupling (ICP OES) (Vista MPX Varian, Mulgrave, Australia), with axial vision and equipped with a $40 \mathrm{MHz}$ radio frequency source (RF), a charged coupled device (CCD) solid state simultaneous multi-element detector, a peristaltic pump, nebulization chamber and sea spray nebulizer. The system was controlled by the ICP Expert software and used 99.996\% pure liquid argon (Air Liquid, SP, Brazil) as the plasma gas.

The optimized experimental conditions for operation of the equipment were: RF power $(1000 \mathrm{~W})$; nebulization gas flow rate $\left(0.9 \mathrm{~L} \mathrm{~min}^{-1}\right)$; principal argon flow rate $\left(15 \mathrm{~L} \mathrm{~min}^{-1}\right)$; auxiliary argon flow rate ( $\left.1.5 \mathrm{~L} \mathrm{~min}^{-1}\right)$; background correction (2 points); integration and reading times $(10 \mathrm{~s})$; number of replicates (3); torch configuration (axial) and wavelengths, As $(188.980 \mathrm{~nm}), \mathrm{Cd}$ $(214.439 \mathrm{~nm}), \quad \mathrm{Cu}(324.754 \mathrm{~nm}), \quad \mathrm{Pb}(220.353 \mathrm{~nm})$ and $\mathrm{Ni}$ $(221.648 \mathrm{~nm})$.

\subsection{Evaluation of inorganic contaminants}

The contents of the inorganic contaminants detected in the cane spirit samples and simulant were evaluated with respect to the maximum levels established by the Brazilian legislation for cane spirit and by the German legislation for wines, since Germany is the main destination for cane spirits produced in Brazil (IBRAC, 2014). The maximum limits in alcoholic beverages for the inorganic contaminants under study, as established by the Brazilian and German legislations are: $\mathrm{Cu}\left(5.0 \mathrm{mg} \mathrm{L}^{-1}\right.$ and $\left.2.0 \mathrm{mg} \mathrm{L}^{-1}\right)$; As $\left(0.100 \mathrm{mg} \mathrm{L}^{-1}\right), \quad \mathrm{Cd} \quad\left(0.020 \mathrm{mg} \mathrm{L}^{-1}\right.$ and $\left.0.010 \mathrm{mg} \mathrm{L}^{-1}\right) ; \quad \mathrm{Pb}$ $\left(0.200 \mathrm{mg} \mathrm{L}^{-1}\right.$ and $\left.0.250 \mathrm{mg} \mathrm{L}^{-1}\right)$, respectively (BGBl, 2002; Ministry of Agriculture, Livestock and Supply, 2005).

The presence of $\mathrm{Ni}$ was considered acceptable if the amount quantified was below $3.0 \mathrm{mg} \mathrm{L}^{-1}$ according to the Brazilian 
legislation and there was no limit for this element in the German legislation (BGBl, 2002; Ministry of Health, 1965).

\subsection{Analytical quality}

The analytical method was validated according to the norms of the Brazilian National Metrology, Normalization and Industrial Quality Institute (INMETRO, 2011) evaluating the following parameters: linearity, sensitivity, (limit of detection - LOD), selectivity, accuracy and precision (repeatability and reproducibility). For precision evaluation, the coefficient of variation was determined using a spiked blank (ethanol solution). For repeatability, seven replicates were measured in one day $(n=7)$ and for reproducibility, seven replicates were measure in two distinct days by the same analyst ( $n=14)$. The accuracy of the method was verified by recovery trials, with the addition of a standard solution of the metals in blank solution (ethanol) at the following concentration levels: low (0.05 $\left.\mathrm{mg} \mathrm{L}^{-1}\right)$, medium $\left(0.30 \mathrm{mg} \mathrm{L}^{-1}\right)$ and high $\left(0.75 \mathrm{mg} \mathrm{L}^{-1}\right)$. For $\mathrm{Cu}$ the same spike levels were used as for the other elements, but at a higher level $\left(5 \mathrm{mg} \mathrm{L}^{-1}\right)$.

\subsection{Statistical analysis}

The experiment installed corresponded to a completely random design (Hinkelmann \& Kempthorne, 2008), with nine treatments (8 cane spirits and one simulant) and three repetitions. The repetitions, or experimental units, corresponded to the in natura soapstone cups in which the cane spirits and the simulant were evaluated.

The concentrations of each element were fitted to a split plot design model (Hinkelmann \& Kempthorne, 2008), with the particularity that the plots in question (in natura soapstone cups) were split according to time and not space. Since cycles cannot be randomized, three possible structures of residual covariance were considered: (i) independent residuals; (ii) compound symmetry and (iii) autoregressive order 1 (Littell, Milliken, Stroup, \& Wolfinger, 1996). The structure of compound symmetry implies that the covariance between two measurements made on the same experimental unit is homogenous, independent of the distance in time, and this corresponds to the classical model of a split plot design in space. These three covariance structures were compared using the Akaike Information Criterion (AIC), the Bayesian Information Criterion (BIC) and the likelihood ratio test (the latter, when applicable).

When there were significant differences $(P<0.05)$ between the cane spirit brands, their means were grouped using the Scott-Knott cluster analysis method (Scott \& Knott, 1974), and when there were significant differences between the evaluation cycles, regression models were fitted. The data were analyzed using $\mathrm{R}$ ( $\mathrm{R}$ Core Team., 2013) and Sisvar (Ferreira, 2011) software environments.

\section{Results and discussion}

\subsection{Analytical quality results}

The method validation was performed according to INMETRO (2011) guidelines. In previous work by our group (Fernandes et al., 2013) the method validation was discussed in detail. Briefly, the figures of merit were successfully evaluated and the proposed method provides a high sensitivity response for all contaminants. No spectral interferences in selected wavelengths were observed and analytical curves provided $r>0.999$. The limits of detection (LOD $=3 s$, being $s=$ standard deviation of 10 analytical blanks) were below $0.003 \mathrm{mg} \mathrm{L}^{-1}$ for all contaminants, except for arsenic (0.006 $\left.\mathrm{mg} \mathrm{L}^{-1}\right)$.
The accuracy evaluation was verified by using an analytical blank spiked at three levels: $0.05 \mathrm{mg} \mathrm{L}^{-1} ; 0.30 \mathrm{mg} \mathrm{L}^{-1}$ and $0.75 \mathrm{mg} \mathrm{L}^{-1}$, and four levels for $\mathrm{Cu}: 0.05 \mathrm{mg} \mathrm{L}^{-1} ; 0.30 \mathrm{mg} \mathrm{L}^{-1}$; $0.75 \mathrm{mg} \mathrm{L}^{-1}$ and $5 \mathrm{mg} \mathrm{L}^{-1}$. Recoveries ranged between $97 \%$ and $118 \%$ for all elements. For precision assessment, the repeatability and reproducibility provided reliable results. Low values of coefficient of variation were for observed for all elements, being below $4 \%$ and $7 \%$. For all expositions, the method was considered appropriate for the evaluation of the inorganic contaminants content in Brazilian spirits storage in raw soapstone cups.

\subsection{Contents of the inorganic elements}

Table 1 shows the concentrations of the inorganic contaminants found in the eight cane spirits and the ethyl alcohol, and also the locations of origin and the respective alcohol contents as stated on the label of each product.

All the alcoholic beverages showed variations in the levels of concentration of all the elements investigated, which were all below the maximum values stipulated by current Brazilian legislation: As $0.025(0.011-0.085) \mathrm{mg} \mathrm{L}^{-1}$, Cd $0.003(0.003-0.004)$ $\mathrm{mg} \mathrm{L}^{-1}, \mathrm{Cu} 2.982(1.113-4.598) \mathrm{mg} \mathrm{L}^{-1}$, Ni 0.01 (0.003-0.020) $\mathrm{mg} \mathrm{L}^{-1}$ and $\mathrm{Pb} 0.024(0.006-0.074) \mathrm{mg} \mathrm{L}^{-1}$. Such variation in the contents of the elements could be attributed to the origin and composition of the distinct beverages used in the present study.

Lachenmeier et al., 2012 reported the maximum levels of As and $\mathrm{Pb}$ in recorded spirits as being 0.000027 and $0.006 \mathrm{mg} \mathrm{L}^{-1}$, respectively. With respect to $\mathrm{Cd}$, the mean values found in the cane spirit samples investigated in the present study $\left(0.003-0.004 \mathrm{mg} \mathrm{L}^{-1}\right)$ were similar to the mean concentrations $\left(0.003 \mathrm{mg} \mathrm{L}^{-1}\right)$ found in white, rosé and red wine samples consumed in Spain (Mena, Cabrera, Lorenzo, \& López, 1995). Lachenmeier et al., 2012 identified the average and maximum levels of $\mathrm{Cd}$ in recorded spirits as 0.000006 and $0.0004 \mathrm{mg} \mathrm{L}^{-1}$ respectively, values that exceed those found in beers and wines. The calculation of the margin of exposure (MOE) in different drinking scenarios for recorded spirits, beers and wine demonstrate that spirits can be more carcinogenic than the other beverages.

In all, the results found in the present study were contrary to those found in other studies carried out with cane spirits from the State of Minas Gerais, Brazil, which showed $\mathrm{Cu}$ contents exceeded the maximum permitted level $\left(5 \mathrm{mg} \mathrm{L}^{-1}\right)$ by percentages varying from $19 \%$ to $25 \%$ (Fernandes et al., 2007; Ibanez et al., 2008).

With respect to the adequacy of these elements to the German legislation (BGBl, 2002), it was observed that the values were below the maximum permitted levels with the exception of $\mathrm{Cu}$, which was found at inappropriate levels in five (62.5\%) of the eight brands of cane spirit studied. Of these beverages, brands C, D, F, G and $\mathrm{H}$ exceeded the legal limit $\left(2 \mathrm{mg} \mathrm{L}^{-1}\right)$ by $97.2 ; 120.5 ; 122.2$; 129.9 and $6.6 \%$, respectively. Nascimento et al. (1999) reported the $\mathrm{Cu}$ content of cane spirits from various regions in Brazil, varying from traces to $14.3 \mathrm{mg} \mathrm{L}^{-1}$, with mean values of $1.67(0.270-$ 3.76) $\mathrm{mg} \mathrm{L}^{-1} ; 4.40$ (ND-14.0) $\mathrm{mg} \mathrm{L}^{-1}$ and 5.01 (0.34-14.3) $\mathrm{mg} \mathrm{L}^{-1}$ according to the category of the sample: export market, national market and small-scale (homebrew) market, respectively. For export category alcoholic beverages, these authors reported mean values of $1.64(\mathrm{ND}-4.59) \mathrm{mg} \mathrm{L}^{-1}$.

\subsection{Contents of the elements in the soapstone exposure trial}

The statistical analysis of the contaminant concentrations comparing the different cane spirit brands in different cycles of exposure to soapstone cups was not carried out for $\mathrm{Cd}$, since the determinations for all the brands in the different exposure cycles always gave values of about $0.003 \mathrm{mg} \mathrm{L}^{-1}$. Of the 108 
Table 1

Origin, labeled alcohol content (\%) and mean concentration and standard derivation ( $\left.\mathrm{mg} \mathrm{L}^{-1}\right)$ of inorganic contaminants in Brazilian spirits.

\begin{tabular}{|c|c|c|c|c|c|c|c|}
\hline \multirow[t]{2}{*}{ Spirits code } & \multirow[t]{2}{*}{ City of origin (MG State) } & \multirow[t]{2}{*}{ Alcohol content (\%) } & \multicolumn{5}{|c|}{ Mean concentration and standard derivation $\left(\mathrm{mg} \mathrm{L}^{-1}\right)$} \\
\hline & & & As & $\mathrm{Cd}$ & $\mathrm{Cu}$ & $\mathrm{Ni}$ & $\mathrm{Pb}$ \\
\hline A & Santa Bárbara & 43.5 & $0.036 \pm 0.001$ & $0.004 \pm 0.001$ & $1.309 \pm 000.1$ & $0.012 \pm 0.005$ & $0.015 \pm 0.001$ \\
\hline $\mathrm{B}$ & Itabirito & 41.0 & $0.011 \pm 0.000$ & $0.003 \pm 0.000$ & $1.906 \pm 0.008$ & $0.014 \pm 0.000$ & $0.006 \pm 0.000$ \\
\hline $\mathrm{C}$ & Brumadinho & 43.0 & $0.011 \pm 0.000$ & $0.003 \pm 0.000$ & $3.945 \pm 0.006$ & $0.020 \pm 0.003$ & $0.074 \pm 0.009$ \\
\hline $\mathrm{D}$ & Sabará & 42.0 & $0.085 \pm 0.000$ & $0.003 \pm 0.000$ & $4.410 \pm 0.006$ & $0.007 \pm 0.000$ & $0.037 \pm 0.001$ \\
\hline $\mathrm{E}$ & Belo Vale & 44.0 & $0.028 \pm 0.004$ & $0.003 \pm 0.000$ & $1.113 \pm 0.003$ & $0.009 \pm 0.001$ & $0.023 \pm 0.001$ \\
\hline $\mathrm{F}$ & Belo Horizonte & 40.0 & $0.011 \pm 0.000$ & $0.003 \pm 0.000$ & $4.444 \pm 0.005$ & $0.006 \pm 0.001$ & $0.029 \pm 0.001$ \\
\hline G & Ouro Preto & 46.0 & $0.011 \pm 0.000$ & $0.004 \pm 0.001$ & $4.598 \pm 0.001$ & $0.008 \pm 0.001$ & $0.006 \pm 0.000$ \\
\hline $\mathrm{H}$ & Congonhas & 45.0 & $0.011 \pm 0.000$ & $0.003 \pm 0.000$ & $2.133 \pm 0.006$ & $0.003 \pm 0.000$ & $0.006 \pm 0.000$ \\
\hline
\end{tabular}

measurements of the experiment, only five differed from this value, corresponding to a single repetition of each of the following combinations: that from cane spirit $B$ with 1 exposure cycle $\left(0.004 \mathrm{mg} \mathrm{L}^{-1}\right)$, that from cane spirit $C$ with 1 exposure cycle $\left(0.005 \mathrm{mg} \mathrm{L}^{-1}\right)$, that from cane spirit $G$ with 1 exposure cycle $\left(0.005 \mathrm{mg} \mathrm{L}^{-1}\right)$, and that from cane spirit $\mathrm{F}$ with 2 exposure cycles $\left(0.004 \mathrm{mg} \mathrm{L}^{-1}\right)$.

For the other contaminants, the likelihood ratio test showed significant residual dependence for the elements $\mathrm{Cu}$ and $\mathrm{Ni}$. This dependence was not significant for the elements $\mathrm{As}$ and $\mathrm{Pb}$ and hence these data were fitted to a model with a treatment factorial structure. Although there was significant residual dependence for the elements $\mathrm{Cu}$ and $\mathrm{Ni}$, it was noted that the compound symmetry and autoregressive structures led to model fittings with very close values of AIC, BIC and the logarithm of the likelihood function. This showed there was no need to consider an autoregressive covariance structure, and thus the classic approach of a split plot design in space was adopted.

Table 2 shows the $F$ statistics of the Analysis of Variance and their $P$-values. For the element As, none of the sources of variation - treatments, exposure cycles and interaction between them were significant. The mean concentration of this contaminant was equal to $0.037 \mathrm{mg} \mathrm{L}^{-1}$.

For the $\mathrm{Pb}$ content, there were significant differences $(P=0.010)$ only between exposure cycles (Table 2 ). Both the cane spirit brands and the interaction between the brands and the exposure cycles presented elevated $P$-values ( 0.805 and 0.837$)$. This suggests that a single regression model could describe the variation in the $\mathrm{Pb}$ concentration as a function of the soapstone exposure cycle. The use of a simple linear regression model indicated a constant fall in the $\mathrm{Pb}$ concentration as the exposure cycles proceeded (Fig. 1), representing an adsorption of the contaminant as a function of the exposure cycles.

Although the cane spirits and simulant showed non-toxic contents of $\mathrm{Pb}$ both before and after contact with soapstone, which is normally free of this element, other authors have reported the contamination with $\mathrm{Pb}$ of alcoholic beverages such as liquor, cognac and whisky (Camean, Moreno, López-Artiquez, Repetto, \& Gonzalez, 2001; Rodushkin, Odman, \& Appelblad, 1999; Vilaykumar \& Ashwini, 2001).

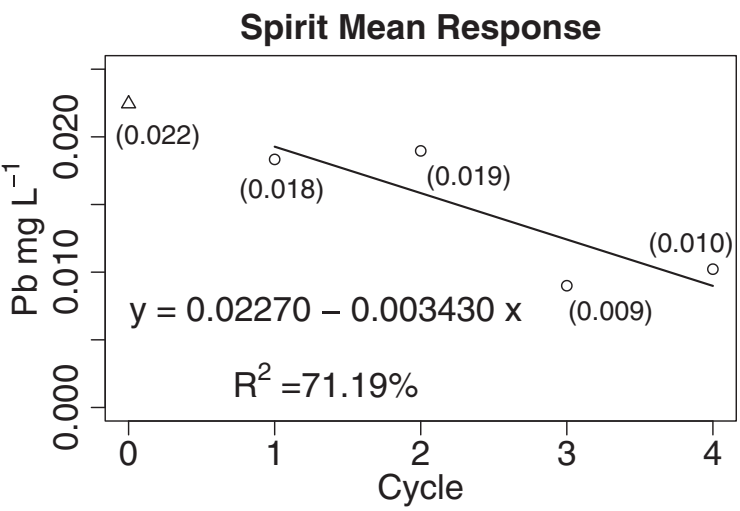

Fig. 1. Regression model of the concentration of $\mathrm{Pb}\left(\mathrm{mg} \mathrm{L}^{-1}\right)$ as a function of exposure cycles to raw soapstone cups; points are means (values between parentheses) calculated using 8 Brazilian spirits. The triangle represents mean $\mathrm{Pb}$ concentration before contact with soapstone.

There was a significant difference between the cane spirit brands with respect to $\mathrm{Ni}$ and also between the exposure cycles (Table 2). Although the interaction between the cane spirits and exposure cycles was not significant at a significance level of 5\%, the cane spirit brands were statistically different with 1 and 2 exposure cycles. These differences became insignificant as from the third exposure cycle to soapstone. This aspect can be seen in Table 3, which presents the clustering of cane spirit means using the Scott-Knott method in each exposure cycle.

The interaction between the cane spirits and exposure cycles was also sliced by brand of cane spirit, fitting distinct regression models for each one, with the Ni concentration as a function of the cycle of exposure to the soapstone cups (Fig. 2). In such models, the independent variable corresponded to the inverse of the number of cycles, chosen to make satisfactory fits possible. The constant term of such models can be interpreted as the value around which the Ni concentration tends to stabilize. For example this concentration was around $0.0076 \mathrm{mg} \mathrm{L}^{-1}$ for brand B. For brand $\mathrm{F}$ a parameter referring to the square of this variable had to be included, in order to prevent significant variation due to lack of

Table 2

F-statistics of the analyses of variance.

\begin{tabular}{|c|c|c|c|c|c|c|c|c|c|c|c|c|c|}
\hline \multirow[t]{2}{*}{ Source of variation } & \multirow[t]{2}{*}{$\mathrm{NDF}^{\mathrm{a}}$} & \multicolumn{3}{|l|}{ As } & \multicolumn{3}{|l|}{$\mathrm{Pb}$} & \multicolumn{3}{|l|}{$\mathrm{Ni}$} & \multicolumn{3}{|l|}{$\mathrm{Cu}$} \\
\hline & & $F$ & $\mathrm{DDF}^{\mathrm{b}}$ & $P$-value & $F$ & $\mathrm{DDF}^{\mathrm{b}}$ & $P$-value & $F$ & $\mathrm{DDF}^{\mathrm{b}}$ & $P$-value & $F$ & $\mathrm{DDF}^{\mathrm{b}}$ & $P$-value \\
\hline Spirits (S) & 8 & 0.64 & 72 & 0.744 & 0.56 & 72 & 0.805 & 4.09 & 18 & 0.006 & 445.84 & 18 & $<0.001$ \\
\hline Cycles (C) & 3 & 0.53 & 72 & 0.661 & 4.05 & 72 & 0.010 & 12.79 & 54 & $<0.001$ & 486.52 & 54 & $<0.001$ \\
\hline $\mathrm{S} \times \mathrm{C}$ & 24 & 0.88 & 72 & 0.631 & 0.7 & 72 & 0.837 & 1.48 & 54 & 0.118 & 33.58 & 54 & $<0.001$ \\
\hline
\end{tabular}

a Numerator degrees of freedom.

b Denominator degrees of freedom. 
Table 3

Concentration of $\mathrm{Ni}$ and $\mathrm{Cu}\left(\mathrm{mg} \mathrm{L}^{-1}\right)$ in Brazilian spirits $(\mathrm{A}-\mathrm{H})$ and in an alcohol beverage simulant (I), before and after 4 cycles of exposure to raw soapstone cups.

\begin{tabular}{|c|c|c|c|c|c|c|c|c|c|c|}
\hline \multirow{2}{*}{$\begin{array}{l}\text { Spirits } \\
\text { code }\end{array}$} & \multicolumn{5}{|c|}{ Ni concentration $\left(\mathrm{mg} \mathrm{L}^{-1}\right)$} & \multicolumn{5}{|c|}{ Cu concentration $\left(\mathrm{mg} \mathrm{L}^{-1}\right)$} \\
\hline & Initial & 1st cycle & 2st cycle & 3st cycle & 4st cycle & Initial & 1st cycle & 2st cycle & 3st cycle & 4st cycle \\
\hline A & 0.012 & $\begin{array}{l}0.012 \mathrm{a} \\
(0.0 \%)\end{array}$ & $\begin{array}{l}0.005 a \\
(-58.3 \%)\end{array}$ & $\begin{array}{l}0.005 \mathrm{a} \\
(-58.3 \%)\end{array}$ & $\begin{array}{l}0.014 \mathrm{a} \\
(16.7 \%)\end{array}$ & 1.309 & $\begin{array}{l}0.834 \mathrm{a} \\
(-36.3 \%)\end{array}$ & $\begin{array}{l}1.074 b \\
(-18.0 \%)\end{array}$ & $\begin{array}{l}1.093 \mathrm{a} \\
(-16.5 \%)\end{array}$ & $\begin{array}{l}1.126 \mathrm{a} \\
(-14.0 \%)\end{array}$ \\
\hline B & 0.014 & $\begin{array}{l}0.029 \mathrm{~b} \\
(107.1 \%)\end{array}$ & $\begin{array}{l}0.019 \mathrm{~b} \\
(35.7 \%)\end{array}$ & $\begin{array}{l}0.014 \mathrm{a} \\
(0.0 \%)\end{array}$ & $\begin{array}{l}0.013 \mathrm{a} \\
(-7.1 \%)\end{array}$ & 1.906 & $\begin{array}{l}1.212 \mathrm{~b} \\
(-36.4 \%)\end{array}$ & $\begin{array}{l}1.420 \mathrm{c} \\
(-25.5 \%)\end{array}$ & $\begin{array}{l}1.389 \mathrm{~b} \\
(-27.1 \%)\end{array}$ & $\begin{array}{l}1.430 \mathrm{~b} \\
(-25.0 \%)\end{array}$ \\
\hline $\mathrm{C}$ & 0.020 & $\begin{array}{l}0.009 \mathrm{a} \\
(-55.0 \%)\end{array}$ & $\begin{array}{l}0.011 \mathrm{a} \\
(-45.0 \%)\end{array}$ & $\begin{array}{l}0.006 \mathrm{a} \\
(-70.0 \%)\end{array}$ & $\begin{array}{l}0.007 \mathrm{a} \\
(-65.0 \%)\end{array}$ & 3.945 & $\begin{array}{l}2.275 \mathrm{c} \\
(-42.3 \%)\end{array}$ & $\begin{array}{l}3.031 \mathrm{~d} \\
(-23.2 \%)\end{array}$ & $\begin{array}{l}3.339 d \\
(-15.4 \%)\end{array}$ & $\begin{array}{l}3.365 d \\
(-14.7 \%)\end{array}$ \\
\hline $\mathrm{D}$ & 0.007 & $\begin{array}{l}0.036 \mathrm{~b} \\
(414.3 \%)\end{array}$ & $\begin{array}{l}0.026 \mathrm{~b} \\
(271.4 \%)\end{array}$ & $\begin{array}{l}0.019 \mathrm{a} \\
(171.4 \%)\end{array}$ & $\begin{array}{l}0.007 \mathrm{a} \\
(0.0 \%)\end{array}$ & 4.410 & $\begin{array}{l}2.826 \mathrm{~d} \\
(-35.9 \%)\end{array}$ & $\begin{array}{l}3.571 \mathrm{e} \\
(-19.0 \%)\end{array}$ & $\begin{array}{l}3.985 \mathrm{e} \\
(-9.6 \%)\end{array}$ & $\begin{array}{l}4.062 \mathrm{e} \\
(-7.9 \%)\end{array}$ \\
\hline E & 0.009 & $\begin{array}{l}0.065 \mathrm{c} \\
(622.2 \%)\end{array}$ & $\begin{array}{l}0.036 \mathrm{~b} \\
(300.0 \%)\end{array}$ & $\begin{array}{l}0.029 \mathrm{a} \\
(222.2 \%)\end{array}$ & $\begin{array}{l}0.035 \mathrm{a} \\
(288.9 \%)\end{array}$ & 1.113 & $\begin{array}{l}0.695 a \\
(-37.6 \%)\end{array}$ & $\begin{array}{l}0.827 \mathrm{a} \\
(-25.7 \%)\end{array}$ & $\begin{array}{l}0.923 \mathrm{a} \\
(-17.1 \%)\end{array}$ & $\begin{array}{l}0.939 a \\
(-15.6 \%)\end{array}$ \\
\hline $\mathrm{F}$ & 0.006 & $\begin{array}{l}0.025 \mathrm{~b} \\
(316.7 \%)\end{array}$ & $\begin{array}{l}0.031 \mathrm{~b} \\
(416.7 \%)\end{array}$ & $\begin{array}{l}0.011 \mathrm{a} \\
(83.3 \%)\end{array}$ & $\begin{array}{l}0.011 \mathrm{a} \\
(83.3 \%)\end{array}$ & 4.444 & $\begin{array}{l}2.745 d \\
(-38.2 \%)\end{array}$ & $\begin{array}{l}3.642 \mathrm{e} \\
(-18.0 \%)\end{array}$ & $\begin{array}{l}3.985 \mathrm{e} \\
(-10.3 \%)\end{array}$ & $\begin{array}{l}4.065 \mathrm{e} \\
(-8.5 \%)\end{array}$ \\
\hline G & 0.008 & $\begin{array}{l}0.030 \mathrm{~b} \\
(275.0 \%)\end{array}$ & $\begin{array}{l}0.022 \mathrm{~b} \\
(175.0 \%)\end{array}$ & $\begin{array}{l}0.015 \mathrm{a} \\
(87.5 \%)\end{array}$ & $\begin{array}{l}0.018 \mathrm{a} \\
(125.0 \%)\end{array}$ & 4.598 & $\begin{array}{l}3.942 \mathrm{e} \\
(-14.3 \%)\end{array}$ & $\begin{array}{l}4.218 \mathrm{f} \\
(-8.3 \%)\end{array}$ & $\begin{array}{l}4.503 \mathrm{f} \\
(-2.1 \%)\end{array}$ & $\begin{array}{l}4.597 \mathrm{f} \\
(0.0 \%)\end{array}$ \\
\hline $\mathrm{H}$ & 0.003 & $\begin{array}{l}0.016 \mathrm{a} \\
(433.3 \%)\end{array}$ & $\begin{array}{l}0.007 \mathrm{a} \\
(133.3 \%)\end{array}$ & $\begin{array}{l}0.006 \mathrm{a} \\
(100.0 \%)\end{array}$ & $\begin{array}{l}0.003 \mathrm{a} \\
(0.0 \%)\end{array}$ & 2.133 & $\begin{array}{l}1.058 \mathrm{~b} \\
(-50.4 \%)\end{array}$ & $\begin{array}{l}1.511 \mathrm{c} \\
(-29.2 \%)\end{array}$ & $\begin{array}{l}1.732 \mathrm{c} \\
(-18.8 \%)\end{array}$ & $\begin{array}{l}1.764 \mathrm{c} \\
(-17.3 \%)\end{array}$ \\
\hline I & 0.003 & $\begin{array}{l}0.009 \mathrm{a} \\
(200.0 \%)\end{array}$ & 0.003 a $(0.0 \%)$ & $\begin{array}{l}0.006 \mathrm{a} \\
(100.0 \%)\end{array}$ & $\begin{array}{l}0.004 \mathrm{a} \\
(33.3 \%)\end{array}$ & 0.086 & $\begin{array}{l}0.112 \mathrm{a} \\
(30.2 \%)\end{array}$ & $\begin{array}{l}0.086 \mathrm{a} \\
(0.0 \%)\end{array}$ & $\begin{array}{l}0.086 \mathrm{a} \\
(0.0 \%)\end{array}$ & $\begin{array}{l}0.086 \mathrm{a} \\
(0.0 \%)\end{array}$ \\
\hline
\end{tabular}

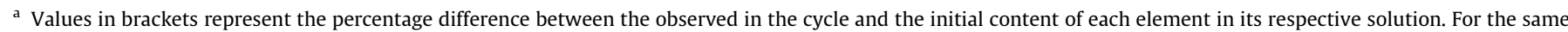
element, means followed by the same letter are statistically similar according to the method of Scott-Knott at 5\% probability.

Spirit B

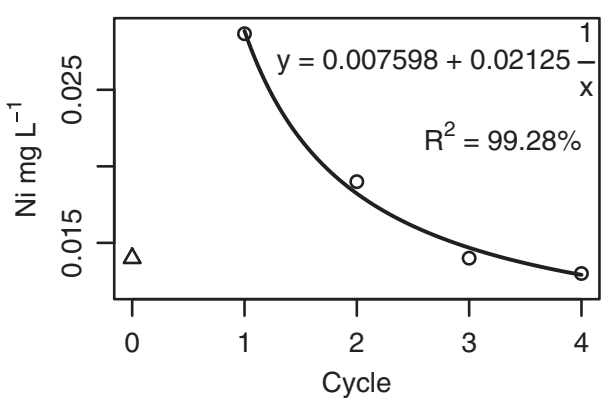

Spirit E

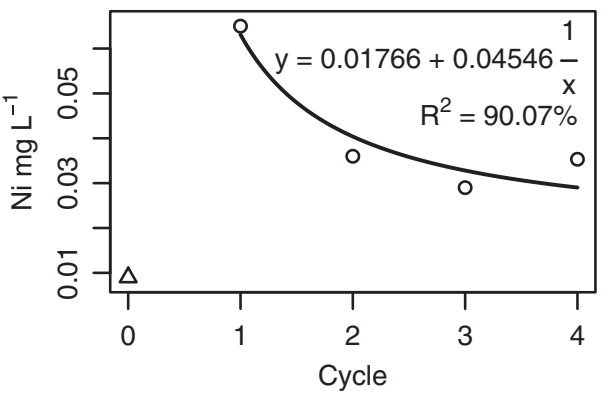

Spirit G

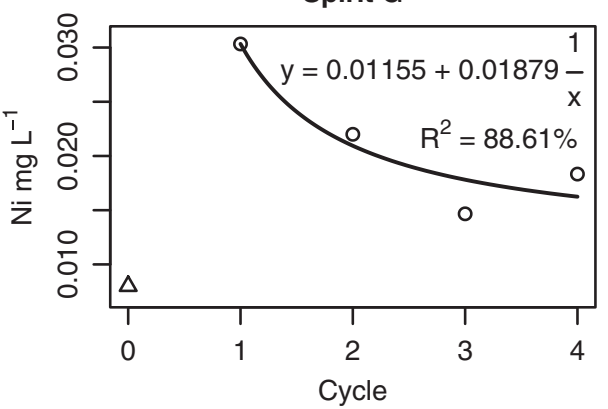

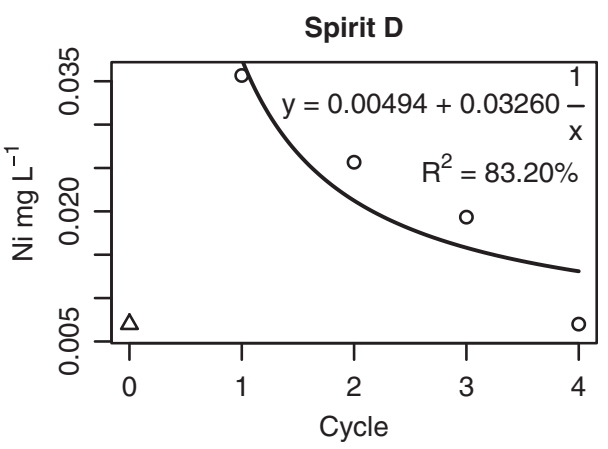

Spirit F

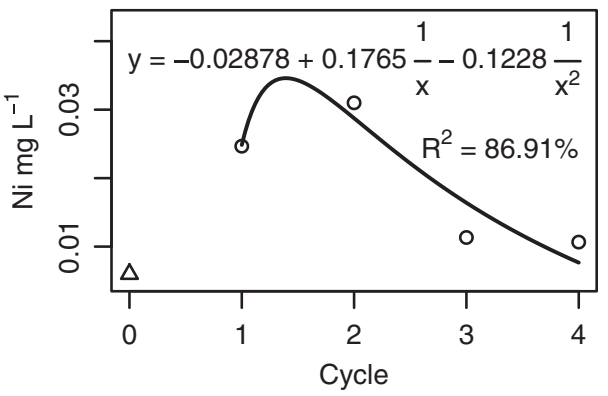
concentrations before contact with soapstone. 
Spirit A

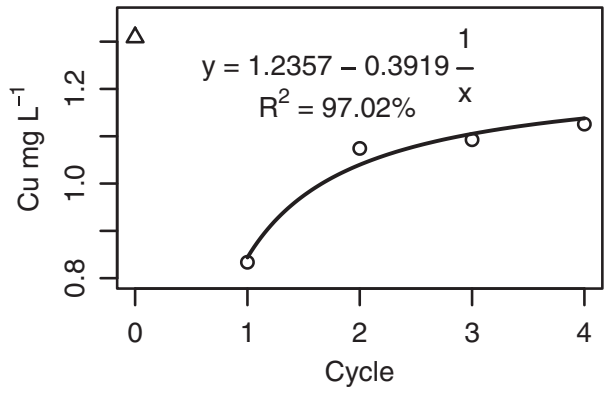

Spirit C

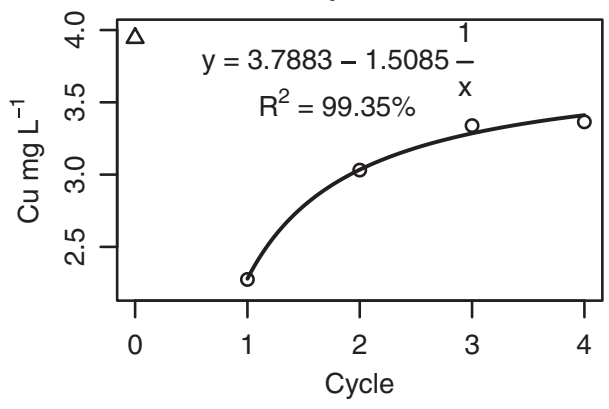

Spirit E

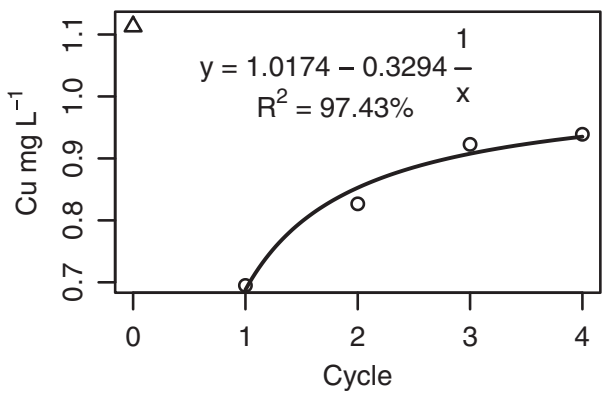

Spirit G

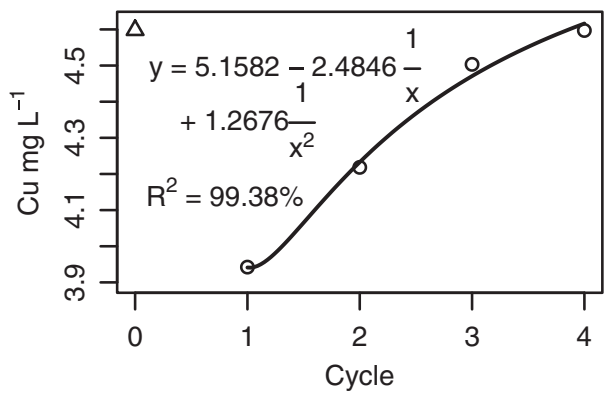

Spirit B

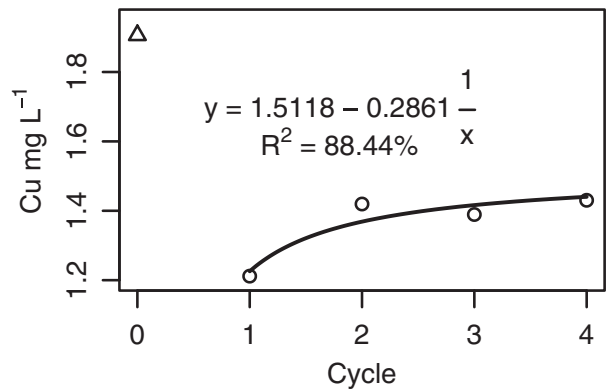

Spirit D

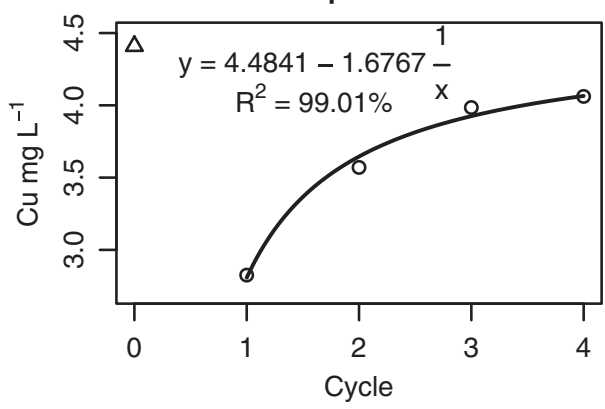

Spirit F

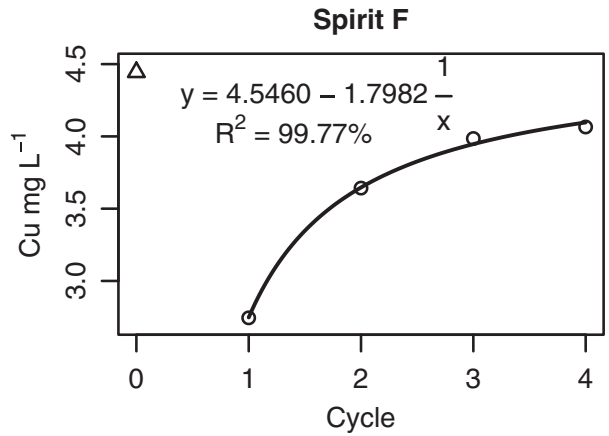

Spirit $\mathbf{H}$

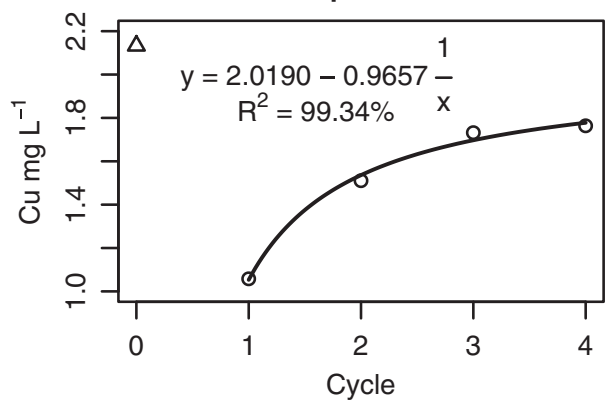

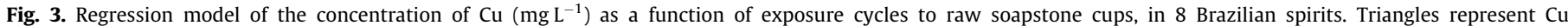
concentrations before contact with soapstone.

fit to the regression model. The estimate of the constant term for this brand was negative, but not significantly different from zero.

The cane spirit brands $A$ and $C$ did not present significant differences between the exposure cycles. The other brands showed a general tendency for the $\mathrm{Ni}$ content to reduce with increase in the number of cycles, although initially contact with the soapstone caused an increase in the content of this contaminant, which can be observed from the position of the points corresponding to the initial values (Fig. 2).
As compared to other transition metals, $\mathrm{Ni}$ is a relatively toxic element in high concentrations (Cempel \& Nikel, 2006), and the presence of such high levels can cause a skin disease known as "nickel-eczema" (Cristensen, Kristiansen, Nielsen, Menne, \& Byrialsen, 1999). Nickel can be used as an alloying metal in stainless steel, a material widely employed in the processing and storage of foods and beverages (Dugo, La Pera, Lo Turco, Di Bella, \& Salvo, 2004), and may therefore be the main non-intentional vehicle of Ni contamination in these products (Cempel \& Nikel, 2006). 
The problem of the transference of $\mathrm{Ni}$ from soapstone to foods and simulants was already documented in a study with a food simulant based on acetic acid at 3.0\% and 5.0\%, in which the in natura soapstone was considered inappropriate for contact with the foods as a function of the transference of harmful amounts of Ni, especially in the test with the more acid solution (Quintaes, 2006; Quintaes, Farfan, Morgano, \& Mantovani, 2002).

However in the present study, although transference of $\mathrm{Ni}$ from the soapstone to the beverages was observed specially during the first cycle of contact (up to $622.2 \%$, brand $\mathrm{E}$ ), the Ni contents always were found conformed to the legal parameters (Table 3 ).

With respect to $\mathrm{Cu}$, significant differences were noted for all sources of variation (Table 2). Since the interaction between cane spirit brands and exposure cycles was significant, the cane spirit brands were compared for each exposure cycle and also the exposure cycles for each cane spirit brand. The cane spirit brand $G$ presented the greatest mean concentration of $\mathrm{Cu}$ in all the exposure cycles (Table 3 ). For the other brands, there were practically no classification changes during the cycles with the exception of brands $\mathrm{H}$ and $\mathrm{B}$, which were classified in the same group for the 1 st and 2nd exposure cycles to the steatite cups, but in different groups for the 3rd and 4th cycles, brand B showing a Cu concentration significantly lower than that of brand $\mathrm{H}$ (Table 3 ).

The cane spirit brands C, D, F, G and $\mathrm{H}$ which initially extrapolated the $\mathrm{Cu}$ content established by the German legislation (BGBl, 2002), presented percent reductions of 42.3 ; 35.9; 38.2; 14.3 and $50.4 \%$ respectively, after the first $24 \mathrm{~h}$ of contact with in natura steatite, favoring the adequacy of brand $\mathrm{H}\left(1.058 \mathrm{mg} \mathrm{L}^{-1}\right)$ to the above mentioned legislation (Table 3 ). $\mathrm{Cu}$ was adsorbed from all such five cane spirit brands in all the cycles, although at a decreasing rate. Thus it can be seen that in general, after the last exposure to soapstone, the cane spirits presented reduction in their $\mathrm{Cu}$ contents of $14.7 ; 7.9 ; 8.5 ; 0.0$; and $17.3 \%$ in relation to the initial concentration, with the exception of brand G. Cane spirit $\mathrm{H}$ was the only brand that became adequate and remained as such for the remaining exposure cycles to the soapstone cups. Cane spirits that were originally adequate (A, B and $\mathrm{E}$ ) remained so throughout the experiment (Table 3).

As can be seen from the fitted regression curves (Fig. 3), there was a tendency for the $\mathrm{Cu}$ concentrations to increase in all the cane spirit brands with the progression of the exposure cycles to the soapstone cups.

For brand $\mathrm{G}$ a parameter associated to the square of the number of exposure cycles had to be included in the model. After this inclusion, lack of fit variation was no longer significant, indicating the adequacy of the model. For the other brands, regression models containing only a constant term and one parameter associated to the inverse of the number of exposure cycles, were satisfactory. In both models the constant term of the model can be interpreted as the value around which the $\mathrm{Cu}$ concentration tended to stabilize as the number of exposure cycles progressed. For brand $\mathrm{A}$, the $\mathrm{Cu}$ concentration tended to stabilize at around $1.236 \mathrm{mg} \mathrm{L}^{-1}$.

The $\mathrm{Cu}$ carried by cane spirit could come from the distillation made in copper stills, with the formation of copper bicarbonate, which could be dissolved by the acidic alcoholic vapors and transmitted to the beverage in an unintentional way (Lima, Cardoso, Guimarães, Lima, \& Nelson, 2009). A study provided evidence of a tendency to correlation between the ethyl carbamate content and the material the still was made of (Aresta, Boscolo, \& Franco, 2001). The utilization of copper-free stills (i.e. stainless steel) represents a good alternative to avoid Cu contamination in cane spirits during production of the beverage.

When considering the $\mathrm{Cu}$ contamination of cane spirits, a recent study showed there could be adsorption of the $\mathrm{Cu}$ present in cane spirits as a function of contact with steatite (Fernandes et al., 2013). Considerable deposits of this material are located in Minas
Gerais (Brazil) in the QFMG region (Deer, Howie, \& Zussman, 1966; Fleischer \& Mandarino, 1995; Roeser, Roeser, Mueller, \& Tobschall, 1980). The great diversity of chemical elements found in the composition of steatite could respond for part of the reported interactions. It should be pointed out that in addition to cups and jars of soapstone, currently the market is commercializing other steatite artifacts that could come into direct contact with beverages, including the sale of soapstone cubes that aim to substitute ice cubes, and could interfere in the final metal concentrations in the beverages.

The results of the present study confirmed that soapstone could adsorb metal elements from cane spirits such as $\mathrm{Cu}$ and $\mathrm{Pb}$, with a notable capacity for $\mathrm{Cu}$ saturation after the first exposure cycle. The adsorption of the metals $\mathrm{Cu}$ and $\mathrm{Pb}$ by the material could be justified by the porosity and/or cleavage of the crystals or by the abrasion the steatite suffers on being lathed to produce a utensil. On the contrary, the origin of the migratory elements in alcoholic beverages could be related to the dissolution of terminal portions of the minerals, broken manually during the manufacture of soapstone cups.

The presence of nickel, principally in samples from the first exposure cycles, could be related to physical ruptures on the surface talcum crystals with damaged edges. One should not ignore the influence of the acidity and alcohol content of the beverages, although these were not quantified. This influence could be an explanation for the differences observed in the migration of $\mathrm{Ni}$ and adsorption of $\mathrm{Cu}$ and $\mathrm{Pb}$ amongst the various cane spirits. Additional studies are required aimed at elucidating the adsorption and migration mechanism of chemical elements by soapstone.

\section{Conclusions}

The cane spirits produced in the Iron Quadrangle (MG, Brazil) that were evaluated in this study conformed with the Brazilian legislation with respect to the contents of the contaminants As 0.025 (0.011-0.085) $\mathrm{mg} \mathrm{L}^{-1}, \mathrm{Cd} 0.003$ (0.003-0.004) $\mathrm{mg} \mathrm{L}^{-1}, \mathrm{Cu} 2.982$ (1.113-4.598) $\mathrm{mg} \mathrm{L}^{-1}$, Ni $0.010(0.003-0.020) \mathrm{mg} \mathrm{L}^{-1}$ and $\mathrm{Pb}$ $0.024(0.006-0.074) \mathrm{mg} \mathrm{L}^{-1}$. However this was not the case with respect to German legislation, since $62.5 \%$ of the brands of cane spirit evaluated showed more than the maximum permitted amount of $\mathrm{Cu}\left(2 \mathrm{mg} \mathrm{L}^{-1}\right)$ by $97.2 ; 120.5 ; 122.2 ; 129.9$ and $6.6 \%$, respectively.

With respect to the behavior of the inorganic contaminants, evidence was found that the contact of alcoholic beverages with in natura soapstone could reduce the $\mathrm{Cu}$ content by up to $50.4 \%$, and increase the Ni content by up to $622.2 \%$, in the first $24 \mathrm{~h}$ of contact. During exposure of the cane spirits to soapstone there was also a linear reduction in the mean $\mathrm{Pb}$ content for all the beverages, varying from $18.3 \%$ to $54.5 \%$ in the first and last cycles, respectively. On the other hand, there was no significant variation in the As and Cd contents during the experiment.

In natura soapstone in contact with alcoholic solutions contaminated with $\mathrm{Cu}$ and $\mathrm{Pb}$ could promote a reduction in the contents of these elements, favoring adequacy of these elements to the parameters established by the legislation, which have a view to the safety of the individuals. However, due to the imminent risk of transferring $\mathrm{Ni}$, steatite should not be in contact with alcoholic beverages which present a content of this element close to the maximum legal limit, since this could represent a health risk to the consumer.

\section{Conflict of interest statement}

The authors declare that they have no conflict of interest. 


\section{Acknowledgements}

The authors are grateful to Oliveira APF and Dedini CA for help with chemical analysis and English review, respectively. Thanks to Fundação de Amparo à Pesquisa do Estado de Minas Gerais (FAPEMIG - Brazil) for the financial support (APQ 01558-09 and APQ02246-14) and to Coordenação de Aperfeiçoamento de Pessoal de Nível Superior (CAPES - Brazil) to the master grant to Louvera Silva KA.

\section{References}

Ajtony, Z., Szoboszlai, N., Suskó, E. K., Mezei, P., György, K., \& Bencs, L. (2008). Direct sample introduction of wines in graphite furnace atomic absorption spectrometry for the simultaneous determination of arsenic, cadmium, copper and lead content. Talanta, 76, 627-634.

Aresta, M., Boscolo, M., \& Franco, D. W. (2001). Copper (II) catalysis in cyanide conversion into ethyl carbamate in spirits and relevant reactions. Journal of Agricultural and Food Chemistry, 49, 2819.

BGBI. Weinverordnung in Der Fassung Der Bekanntmachung. vom 14. Mai 2002 (BGBl. I, S. 1583), zuletzt geändert durch die Verordnung vom 28. März 2003 (BGBl. I, S. 453).

Caldas, N. M., Raposo, J. L., Jr., Gomes Neto, J. A., \& Barbosa, F. Jr., (2009). Effect of modifiers for As, $\mathrm{Cu}$ and $\mathrm{Pb}$ determinations in sugar-cane spirits by GF AAS. Food Chemistry, 113, 1266-1271.

Camean, A. M., Moreno, I., López-Artiquez, M., Repetto, M. A., \& Gonzalez, A. G. (2001). Differentiation of Spanish brandies according to their metal content. Talanta, 54, 53-59.

Cempel, M., \& Nikel, G. (2006). Nickel: A review of its sources and environmental toxicology. Polish Journal of Environmental Studies, 15, 375-382.

CEPA. Conselho Estadual de Política Agrícola. Câmara Técnica de Cachaça de Alambique. Plano setorial da cachaça de alambique. Belo Horizonte, Minas Gerais. 2008. 14 p.

Cristensen, J. M., Kristiansen, J., Nielsen, N. H., Menne, T., \& Byrialsen, K. (1999). Nickel concentrations in serum and urine of patients with nickel eczema. Toxicology Letters, 108, 185-189.

Deer, W. A., Howie, R. A., \& Zussman, J. (1966). An Introduction to the Rock Forming Minerals. Essex: Longman Press.

Dugo, G., La Pera, L., Lo Turco, V., Di Bella, G., \& Salvo, F. J. (2004). Determination of $\mathrm{Ni}$ (II) in beverages without any sample pre-treatment by adsorptive stripping chronopotentiometry (AdSCP). Journal of Agricultural and Food Chemistry, 52, 1829-1834.

Fernandes, J. W., Cardoso, M. G., Vilela, F. J., Morais, A. R., Silva, V. F., \& Nelson, D. L. (2007). Physicochemical quality of a blend of domestic cachaças from the south of Minas Gerais. Journal Food Composition and Analysis, 20, 257-261.

Fernandes, I. C., Fausto, M. A., Bezerra, O. M. P. A., Quintaes, K. D., Morgano, M. A., \& Cerqueira, I. B. (2013). Levels of inorganic contaminants in Brazilian cachaças from the Quadrilatero Ferrífero region stored in steatite (soapstone) in natura cups. Quimica Nova, 36, 1360-1365.

Ferreira, D. F. (2011). Sisvar: A computer statistical analysis system. Ciência e Agrotecnologia, 35, 1039-1042.

Fleischer, M., \& Mandarino, J. A. (1995). Glossary of mineral species. Tucson: The Mineralogical Record, Inc. 280p.

Hinkelmann, K., \& Kempthorne, O. (2008). Design and analysis of experiments (Vol. 1). Hoboken: John Wiley \& Sons. 631p.

Ibanez, J. G., Carreon-Alvarez, A., Barcena-Soto, M., \& Casillas, N. (2008). Metals in alcoholic beverages: A review of sources, effects, concentrations, removal, speciation, and analysis. Journal Food Composition and Analysis, 21, 672-683.

IBRAC. (2014). Instituto Brasileiro da Cachaça. Fonte: MDIC - ALICEWEB - NCM 2208.40.00/Elaboração: Instituto Brasileiro da Cachaça - IBRAC. Brasília,
Distrito Federal. URL <http://www.ibraccachacas.org/index.php/servicos/ estatisticas/mercado-externo $>$ Accessed 02.10.14

INMETRO - Instituto Nacional de Metrologia, Normalização e Qualidade Industrial Orientação Sobre Validação de Métodos Analíticos. DOQ-CGCRE-008. Rev.: 04 1-20, Jul. 2011.

Lachenmeier, D. W., Przybylski, M. C., \& Rehm, J. (2012). Comparative risk assessment of carcinogens in alcoholic beverages using the margin of exposure approach. International Journal of Cancer, 131, E995-E1003. http:// dx.doi.org/10.1002/ijc.27553.

Lima, A. J. B., Cardoso, M. G., Guimarães, L. G. L., Lima, J. M., \& Nelson, D. L. (2009) Efeito de substâncias empregadas para remoção de cobre sobre o teor de compostos secundários da cachaça. Quimica Nova, 32, 845-848.

Littell, R. C., Milliken, G. A., Stroup, W. W., \& Wolfinger, R. D. (1996). SAS ${ }^{\circledR}$ system for mixed models. Cary, NC: SAS Institute Inc. 633p.

López-Artíguez, M., Cameán, A. M., \& Repetto, M. (1996). Determination of nine elements in sherry wine by inductively coupled plasma-atomic emission spectrometry. Journal of AOAC International, 79, 1191-1197.

Mena, C., Cabrera, C., Lorenzo, M. L., \& López, M. C. (1995). Cadmium levels in wine, beer and other alcoholic beverages: Possible sources of contamination. The Science of the Total Environment, 181, 201-208.

Ministry of Agriculture, Livestock and Supply. Instrução Normativa n ${ }^{\circ} 13$, de 29/06/ 2005. Padrões de identidade e qualidade para aguardente de cana e para cachaça. Diário Oficial [da] República Federativa do Brasil. Brasília, DF, 30 jun. 2005.

Ministry of Health. Agência Nacional de Vigilância Sanitária. Decreto n 55.871, de 26 de março de 1965. Diário Oficial [da] República Federativa do Brasil. Brasília, DF, 9 abr. 1965.

Nascimento, R. F., Bezerra, C. W. B., Furuya, S. M. B., Schultz, M. S., Polastro, L. R. Lima Neto, B. S., \& Franco, D. W. (1999). Mineral profile of Brazilian cachaças and other international spirits. Journal Food Composition and Analysis, 12, 17-25.

Quintaes, K. D. (2006). A influência da composição do esteatito (pedra-sabão) na migração de minerais para os alimentos: Minerais do esteatito. Cerâmica, 52 298-305.

Quintaes, K. D., Farfan, J. A., Morgano, M. A., \& Mantovani, D. M. B. (2002). Soapstone (steatite) cookware as a source of minerals. Food Additives Contaminants, 19 $134-143$.

R Core Team. (2013). R: A language and environment for statistical computing. Vienna: $\mathrm{R}$ Foundation for Statistical Computing, URL <http://www.R-project.org/> Accessed 13.02.15.

Rodushkin, I., Odman, F. \& Appelblad, P. K. (1999). Multielement determination and lead isotope ratio measurement in alcoholic beverages by high-resolution inductively coupled plasma mass spectrometry. Journal Food Composition and Analysis, 12, 243-257.

Roeser, U., Roeser, H., Mueller, G., \& Tobschall, H. J. (1980). Anais do XXXI Congresso Brasileiro de Geologia, 4, 2230-2245.

Scott, A. J., \& Knott, M. A. (1974). A cluster analysis method for grouping means in the analysis of variance. Biometrics, 30, 507-512.

Siebalde, H. G. L., Canuto, M. H., Lima, G. M., \& Silva, J. B. B. (2002). Informe Agropecuário, 23, 59.

Soufleros, E. H., Mygdalia, A. S., \& Natskoulis, P. (2004). Characterization and safety evaluation of the traditional Greek fruit distillate "Mouro" by flavor compounds and mineral analysis. Food Chemistry, 86, 625-636.

Statista. The statistics portal. Revenue forecast of the global spirits industry from 2009 to 2015 (in billion U.S. dollars). URL < http://www.statista.com/statistics/233496/ revenue-forecast-of-the-global-spirits-industry> Accessed 03.12.15.

Vilaykumar, S. I., \& Ashwini, K. A. (2001). Voltammetric determination of lead at chemically modified electrodes bases on crown ethers. Analytical Sciences, 17, 605-608.

WHO, World Health Organization. (2014). Global status report on alcohol and health. Geneva, Switzerland. URL <http://www.who.int/substance_abuse/ publications/global_alcohol_report/msb_gsr_2014_1.pdf $>$ Accessed 03.12.15. 